\title{
A Paleoneurohistological Study of 3,000-Year-Old Mummified Brain Tissue from the Mediterranean Bronze Age
}

\author{
Gemma Prats-Muñoz $^{\mathrm{e}}$ Assumpció Malgosa ${ }^{\mathrm{e}}$ Nuria Armentano ${ }^{\mathrm{e}}$ \\ Ignasi Galtés ${ }^{c, e}$ Jordi Esteban ${ }^{b}$ Josep A. Bombi ${ }^{b}$ Montserrat Tortosa ${ }^{b}$ \\ Eva Fernández $^{b} \quad$ Xavier Jordana $^{d}$ Albert Isidro $^{f}$ Josep M. Fullola ${ }^{a}$ \\ M. Àngels Petit ${ }^{a}$ Victor M. Guerrero ${ }^{g}$ Manuel Calvo $^{g}$ Pedro L. Fernández $^{b}$ \\ a Seminar of Prehistoric Studies and Research, Department of Prehistory, Ancient History and Archaeology, \\ and ${ }^{b}$ Department of Pathology, Hospital Clínic and Institut d'Investigacions August Pi i Sunyer, University of

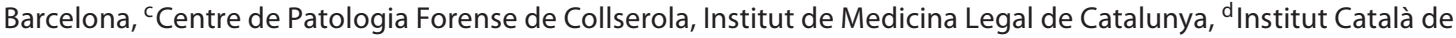 \\ Paleontologia Miquel Crusafont, and 'Unitat d'Antropologia Biològica, Departament BABVE, Universitat Autònoma \\ de Barcelona, and ${ }^{\mathrm{f} S e r v i c i o ~ C O T}$, Hospital Universitari Sagrat Cor, Barcelona, and 9 Departament de Ciències \\ Històriques i Teoria de les Arts, Àrea de Prehistòria, Universitat de les Illes Balears, Palma de Mallorca, Spain
}

\section{Key Words}

Bronze Age $\cdot$ Mummy $\cdot$ Nervous system $\cdot$ Paleopathology $\cdot$ Talaiotic culture

\footnotetext{
Abstract

Objectives: Mummified nervous tissue is very rarely found in ancient remains and usually corresponds to corpses which were frozen or preserved in bogs, conditions which limit tissue autolysis and bacterial degradation. Here, we show the unusual finding of spontaneously mummified brain tissue from several individuals from the little known megalithic talaiotic culture of the island of Minorca, dating approximately 3,000 years before present and corresponding to the late Mediterranean Bronze Age. Methods: These individuals were part of an intact burial site containing 66 subjects. Intracraneal samples were carefully rehydrated with Sandison's solution. We used classical histochemical as well as 2D and 3D (scanning) electron-microscopic techniques. $\boldsymbol{R e}$ sults: We provide evidence of the nervous nature of the sam-
}

ples as well as a detailed description of the morphological features of these ancient tissues. The intracranial material consisted of well-preserved eosinophilic reticular tissue and, although mostly absent, some exceptional pigment-containing neurons were identified. Conclusions: We present a detailed morphological analysis which can provide valuable information and guidelines for the interpretation of this scarce type of mummified samples and provide explanations for this surprising preservation.

Copyright $\odot 2012$ S. Karger AG, Basel

\section{Introduction}

In the spring of 2005 , three speleologists climbed to the 15-meter-high entrance of a 6.5-meter-deep karstic cave located on an inland cliff on the island of Minorca (fig. 1). Their first glance from the entrance to the interior of the cave showed what they immediately recognized as osseous remnants and hair, prompting them to return to the city

\section{KARGER \\ Fax +4161306 1234 \\ E-Mail karger@karger.ch}

www.karger.com (c) 2012 S. Karger AG, Basel

$1015-2008 / 12 / 0795-0239 \$ 38.00 / 0$

Accessible online at:

www.karger.com/pat
Dr. Pedro L. Fernández, MD, $\mathrm{PhD}$

Department of Pathology, Hospital Clinic

Villarroel 170

ES-08036 Barcelona (Spain)

Tel. +3493 337 5450, E-Mail plfernan@ @linic.ub.es 
Fig. 1. The 15-meter-high entrance (arrow) to the 'Cova des Pas' (cave of the steps) on an inland cliff in Minorca (Spain).

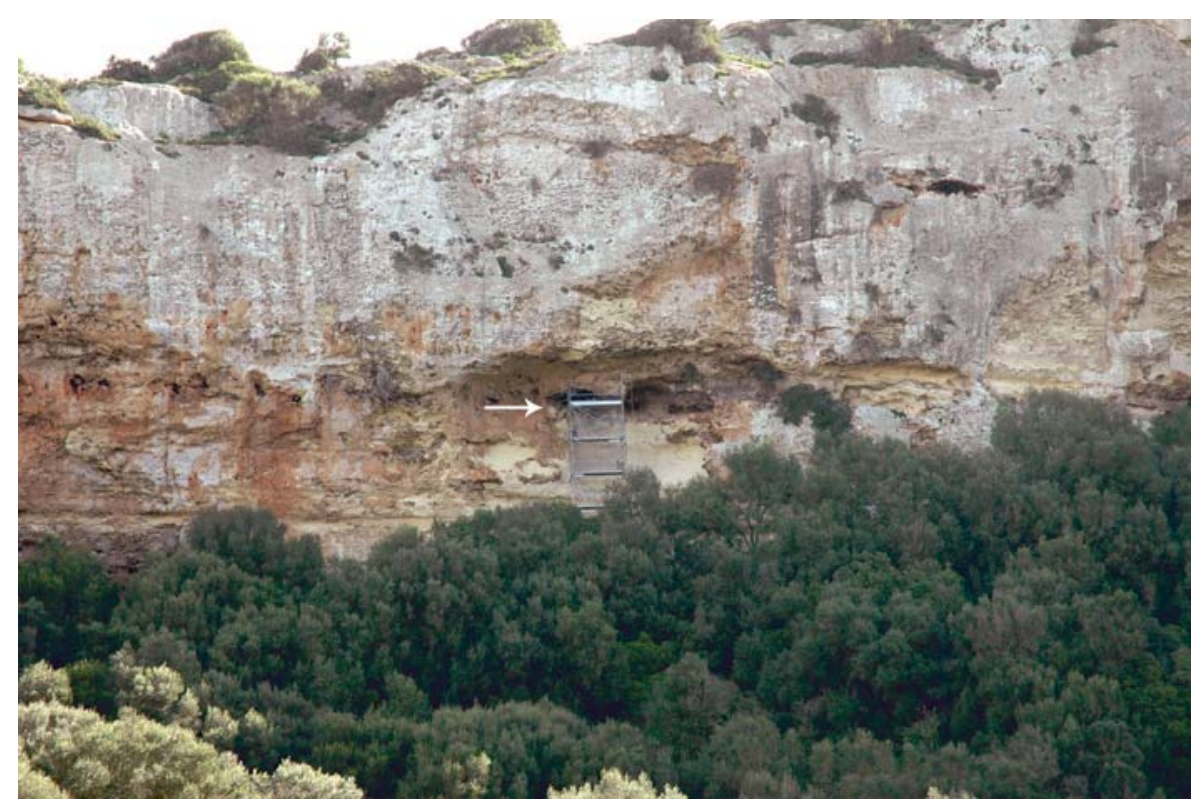

and inform the public authorities, who diligently closed the site for further investigation. Archaeological studies revealed a burial site with a great number of individuals organized in several layers piled up at the bottom of the cave. Most of the individuals were bundled laterally in a fetal position with ropes and animal hides (fig. 2). Tin hair needles and some bronze bracelets reflect the high status of some of these individuals due to the scarcity of this metal on the island. Besides human remnants, different artifacts were recorded, including stretchers, floral blankets and bull-hide containers with hair inside. ${ }^{14} \mathrm{C}$ analyses of different samples estimated that burial activity took place during a short period in the late Bronze Age, from 900 to $800 \mathrm{BC}$ [1], which corresponded to the talaiotic culture ('talayots' are stone table-shaped funerary and defensive constructions typical of this culture). Sixty-six individuals were finally identified at different levels, including 27 infants, 5 juveniles and 34 adults of both sexes. The abundant osseous remnants are still under analysis and have so far provided evidence of periostitis, cribra orbitalia, degenerative vertebral changes, osteochondritis and two probable neoplasms involving a femur and a coxal.

Although the anthropological and paleopathological analyses are far from completion at this point, it is now evident that abundant soft tissue elements have remained preserved in several individuals. Among these, muscle attached to the long bones, intrathoracic and abdominal content and, most interestingly, intracranial tissue were readily discovered in 4 individuals: No. 1 (female, age 25-
30 years), 6 (female, age 5-7 years), 22 (male, age 40-50 years) and 41 (female, age $35-40$ years; fig. 3 ).

In this study, we provide interesting clues for the interpretation of both light- and electron-microscopic analyses of ancient nervous system samples, which could help to better understand findings of such unique material of future paleoneurohistological projects.

\section{Materials and Methods}

Samples of the intracranial content of the 4 individuals were carefully rehydrated with Sandison's solution [2] for 30-60 min, depending on the size of the sample, and thereafter embedded in paraffin, sectioned at $3 \mu \mathrm{m}$ and stained with hematoxylin-eosin, Masson's trichrome and periodic acid-Schiff stain (PAS). Based on previous studies reporting sporadic success in this type of studies $[3,4]$, the expression of several immunohistochemical markers (neuron-specific enolase, Neu-N, glial fibrillary acidic protein, S100 protein, neurofilaments, CD56 and actin) was studied using primary monoclonal antibodies (table 1) detected with the EnVision Flex system (Dako, Glostrup) and diaminobenzidine as chromogen.

Samples for ultrastructural analysis were fixed in $2 \%$ glutaraldehyde for transmission electron microscopy. After fixation in $2 \%$ osmium tetroxide, the samples were dehydrated according to standard techniques and embedded in Araldite (Durcupan ACM). Thin sections were stained with uranyl acetate and lead citrate and examined with a JEOL 1200EX II transmission electron microscope. Scanning electron microscopy (Hitachi S-2300) was performed on 2 samples which were processed in glutaraldehyde for $30 \mathrm{~min}$, then underwent critical-point drying and were coated with gold by a sputtering process. 
Fig. 2. Most individuals were buried in a lateral, fetal position.

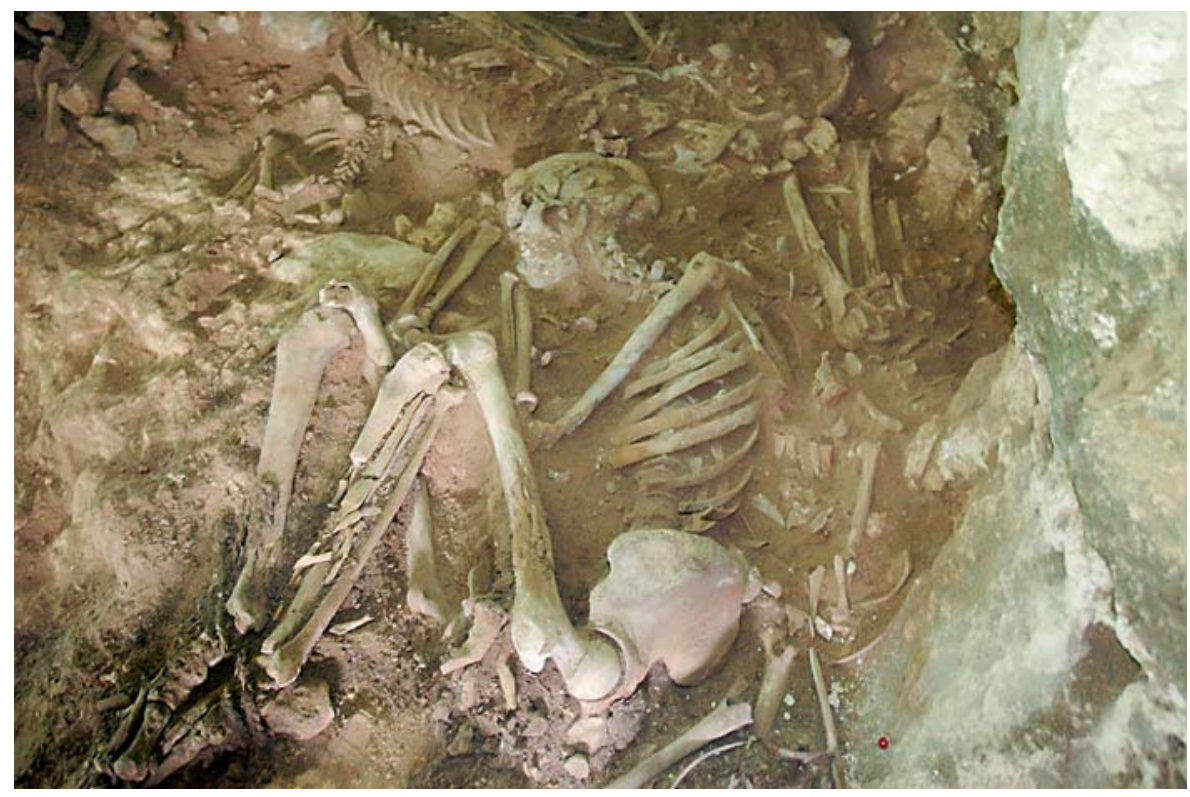

Table 1. Antibodies (type, dilution, pretreatment and source) used in immunohistochemistry

\begin{tabular}{lllll}
\hline Antibody & Clone & Dilution & Pretreatment & Source \\
\hline S100 protein & polyclonal & prediluted & EDTA buffer pH 9 & DAKO \\
Neu-N & Mab37 & $1 / 500$ & citrate buffer pH 6 & Millipore \\
GFAP & polyclonal & prediluted & citrate buffer pH 6 & DAKO \\
CD56 & 123C3 & prediluted & EDTA buffer pH 9 & DAKO \\
NSE & BBS & prediluted & EDTA buffer pH 9 & DAKO \\
Actin & HHF35 & $1 / 200$ & EDTA buffer pH 9 & DAKO \\
\hline
\end{tabular}

GFAP = Glial fibrillar acidic protein; NSE = neuron-specific enolase.

\section{Results}

Light microscopy showed a similar histological pattern in the intracranial tissue samples from the 4 individuals with well-preserved eosinophilic reticular tissue, which, in some areas, was partially covered by a thick fibrous layer consistent with the dura mater, under which areas with abundant round 20 - to $40-\mu \mathrm{m}$ empty spaces suggested neuronal locations in the brain cortex (fig. 4, 5). Some larger spaces contained concentrical structures reminiscent of vessels inside the cortex (fig. 6). Careful examination revealed rare areas in individual No. 41 , in which aggregates of round-to-ovoid pallid and granular structures measuring $15-20 \mu \mathrm{m}$ in the greatest diameter were interpreted as brain nuclei (fig. 7). Nearby, other individual structures contained PAS-positive granular ma- terial and others displayed brown pigment consistent with neurons of the locus ceruleus or substantia nigra, thus suggesting a location in the midbrain (fig. 8). Moreover, in few instances, nuclear remnants were observed (fig. 9). Finally, round and oval aggregates of fibrillary structures were considered to represent nerve fascicles traversing the white matter or ganglia (fig. 10, 11). Microscopic images were compared with bona fide naturally mummified brain tissue from a local cemetery dating approximately 100 years ago, and histological features were similar, but no well-preserved neuron was found in the latter. All putative brain samples, including that of the 'modern' mummy, showed the consistent presence of small $(50-100 \mu \mathrm{m})$ spherical structures at the periphery of the tissue with histological features similar to those of the rest of the sample, which we interpreted as a specif- 


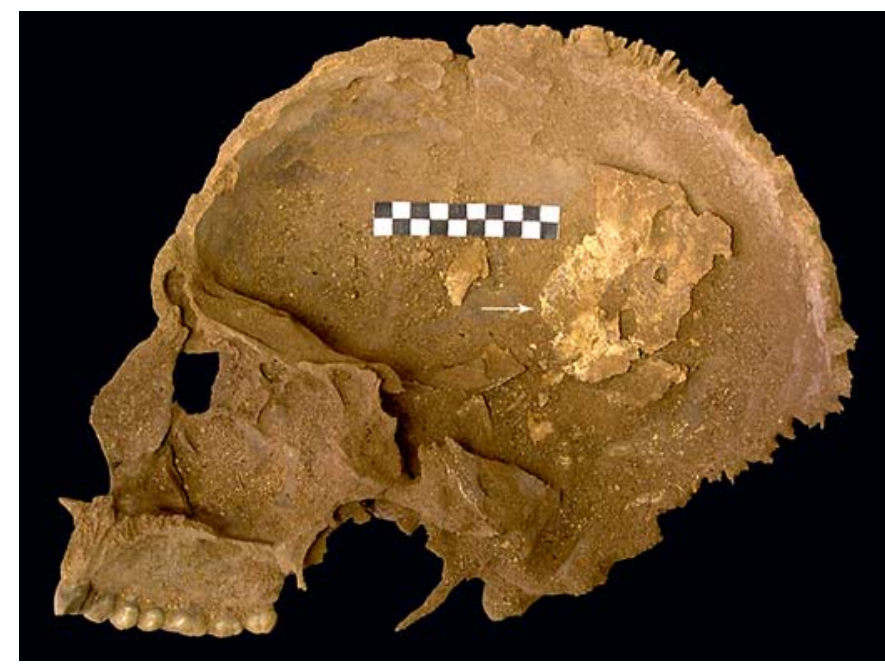

Fig. 3. Skull of individual No. 1 with brittle, whitish material attached to the right parietal bone (arrow).

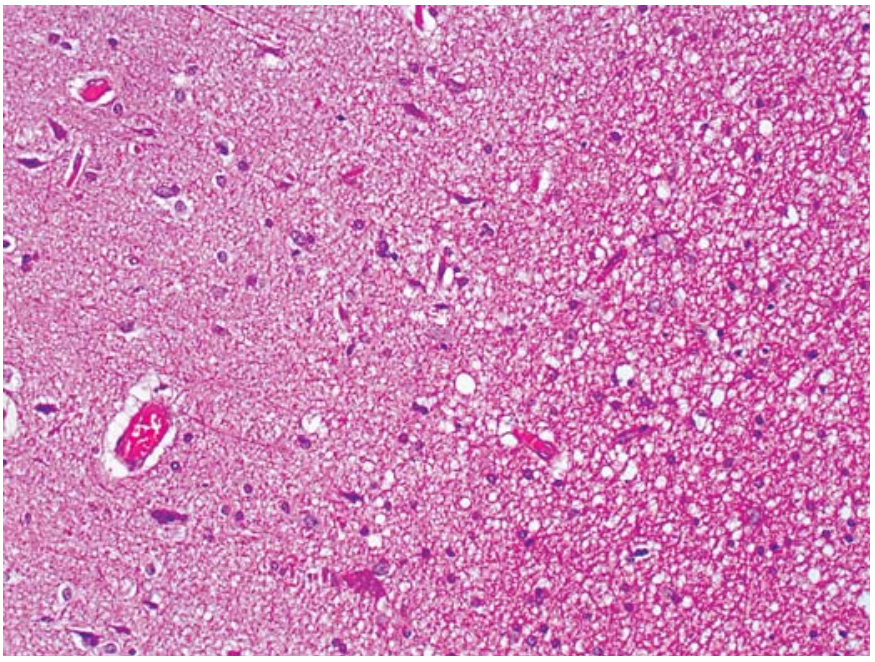

Fig. 5. Histological section of a modern brain for comparison with figures 4 and 6 showing vascular spaces on a reticular background and cortical neurons (left half). HE, $\times 100$.

ic form of mummified nervous tissue disintegration (fig. 12). Immunohistochemical staining for all neural markers and actin were negative, as expected from previous studies on cerebral tissue [5]. Trichrome staining did not provide additional information due to the homoge-

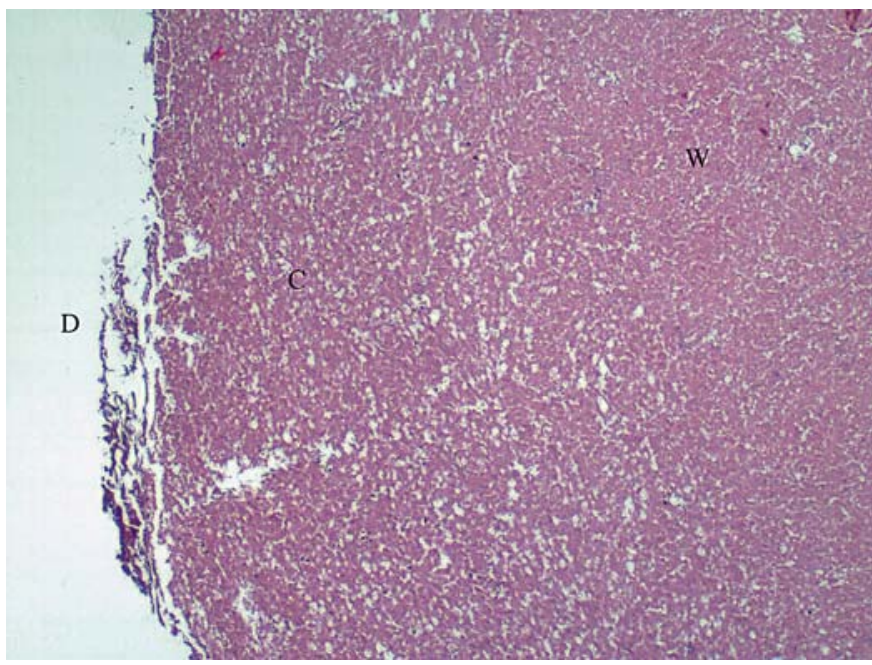

Fig. 4. Low-power view of rehydrated intracranial tissue of individual No. 41 . The condensed laminar structure on the surface is suggestive of the dura mater (D), whereas the remaining tissue shows topographical differences: the outermost area displays small round spaces consistent with the cerebral cortex $(C)$, whereas a more reticular and dense tissue was observed in the innermost region $(\mathrm{W})$, which was interpreted as white matter. $\mathrm{HE}, \times 40$.

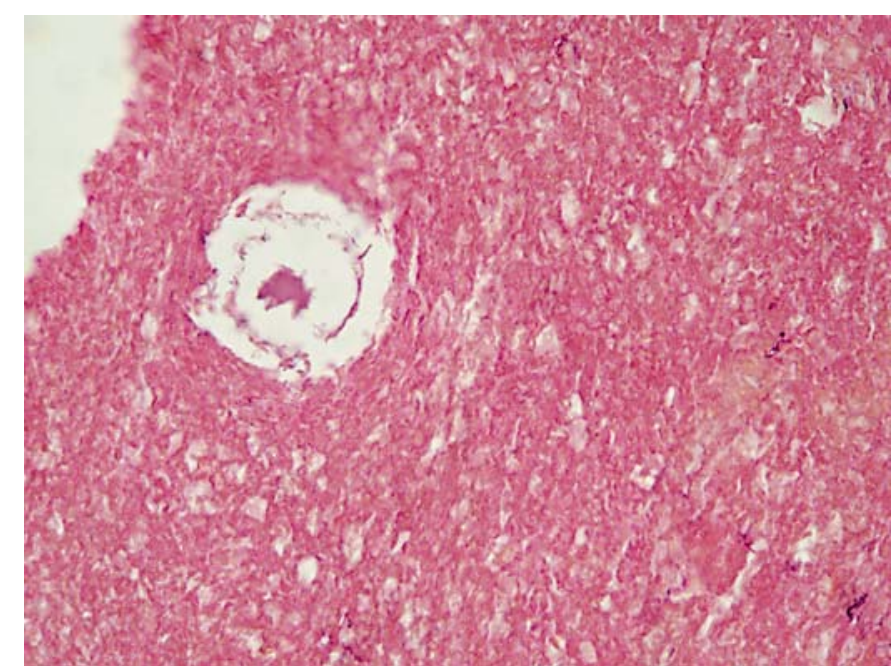

Fig. 6. Histological section of mummified intracranial material from individual No. 1 showing reticular tissue with a round space consistent with a vascular and perivascular space. $\mathrm{HE}, \times 200$.

neous results in all areas. Contrarily, Luxol-fast blue stain for myelin was strongly positive (not shown).

Scanning electron microscopy confirmed the reticular appearance of the samples (fig. 13) consistent with nervous tissue and identified vascular spaces (fig. 14). 


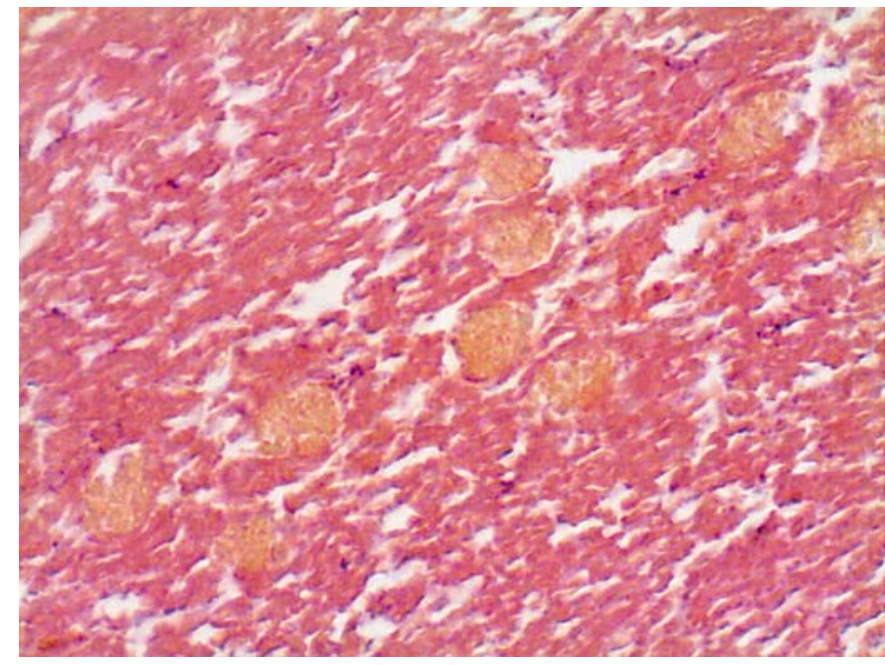

Fig. 7. Discrete oval grouped elements with pallid staining suggesting a brain nucleus. HE, $\times 600$.

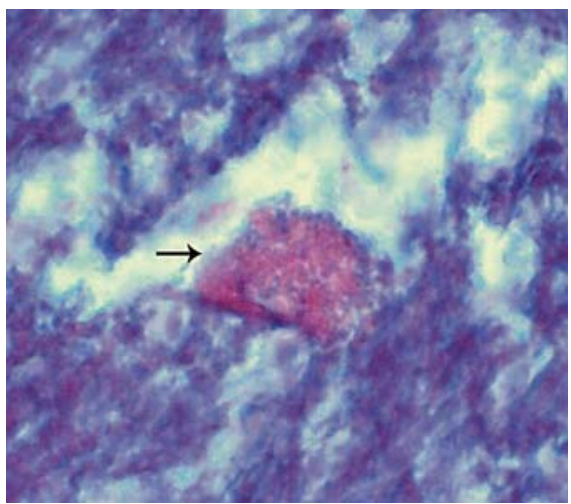

Fig. 9. High-power view of a polygonal element with granular cytoplasmic content and likely nuclear remains (arrow). HE, $\times 600$.

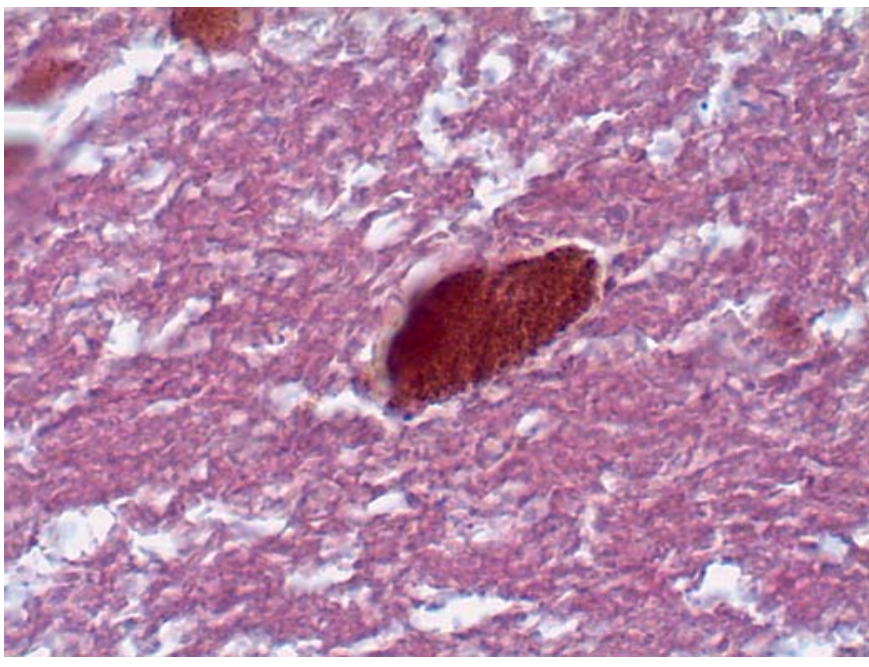

Fig. 8. High-power view of a pigment-containing neuron. HE, original magnification $\times 600$.

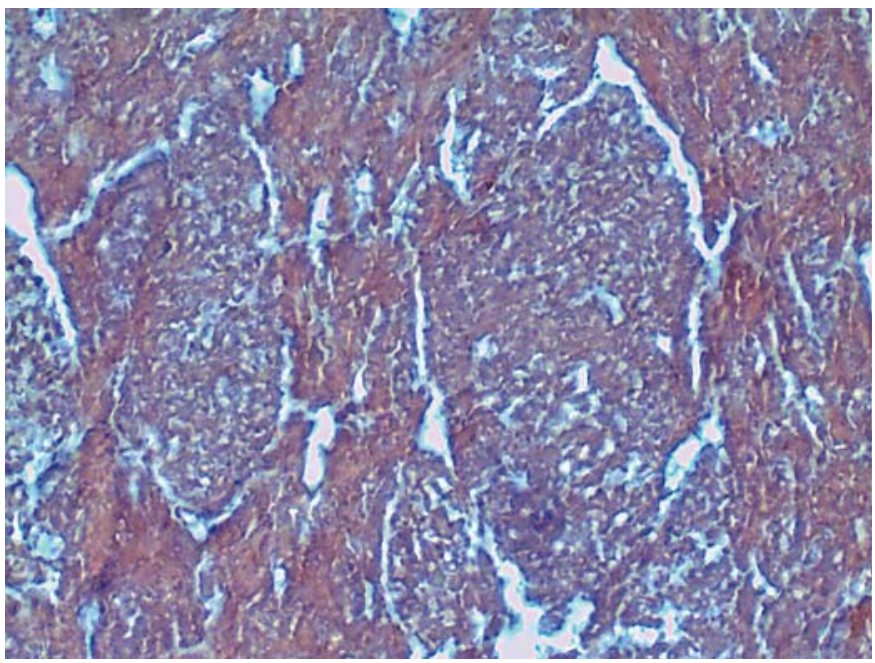

Fig. 10. Oval condensations inside reticular background indicative of nerve fascicles traversing white matter or ganglia. HE, $\times 400$.

nal and internal morphology of animal or human corpses by a rapid desiccation process commonly called mummification. Nonetheless, even in the better-preserved subjects, there are organs and tissues which, due to their high enzymatic content and/or lack of fibromuscular stroma (pancreas, salivary glands, prostate and adrenal gland), undergo quick degradation and virtually disappear. One such organ is the central nervous system, with few accounts of its discovery as mummified tissue for the above reasons. 


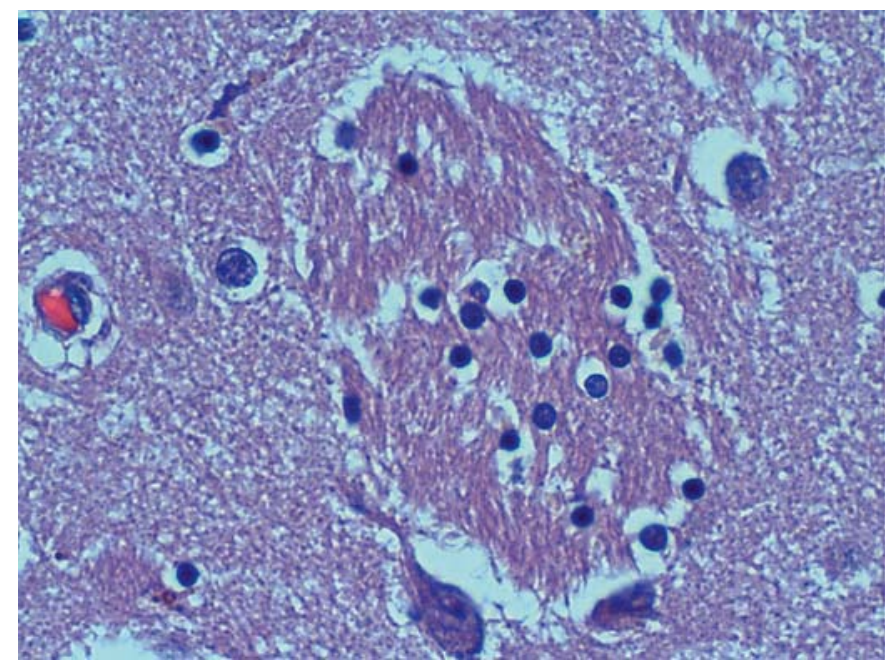

Fig. 11. Structures similar to those seen in figure 10 are presented, for comparison, in this area of nerve fascicles traversing the nucleus caudatus in a modern brain. HE, $\times 400$.

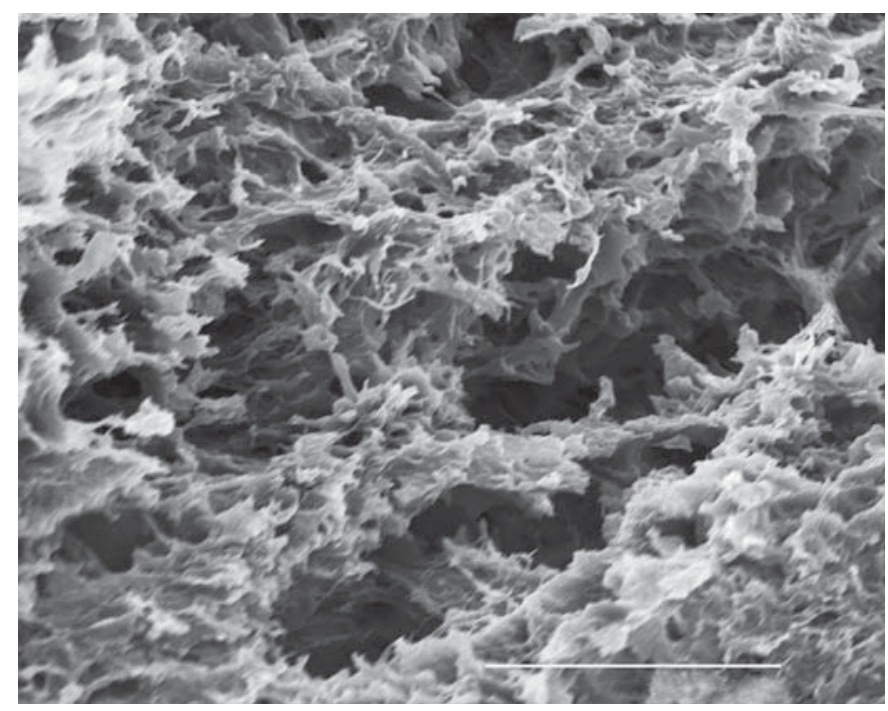

Fig. 13. Scanning 3D electron microscopy of intracranial material of individual No. 1 showing a reticular pattern typical of brain tissue. Scale bar: $50 \mu \mathrm{m}$.

Findings of brain tissue are anecdotic in the already rare mummified subjects [6] and when this happens, mostly in frozen mummies, it is usually subject to the most sophisticated techniques to prove its neural origin. Early reports date back to 1902, when Elliot-Smith [7] described spontaneous mummification of brains in ancient Egypt. Later, in 1927, Aichel [8] briefly mentioned recog-

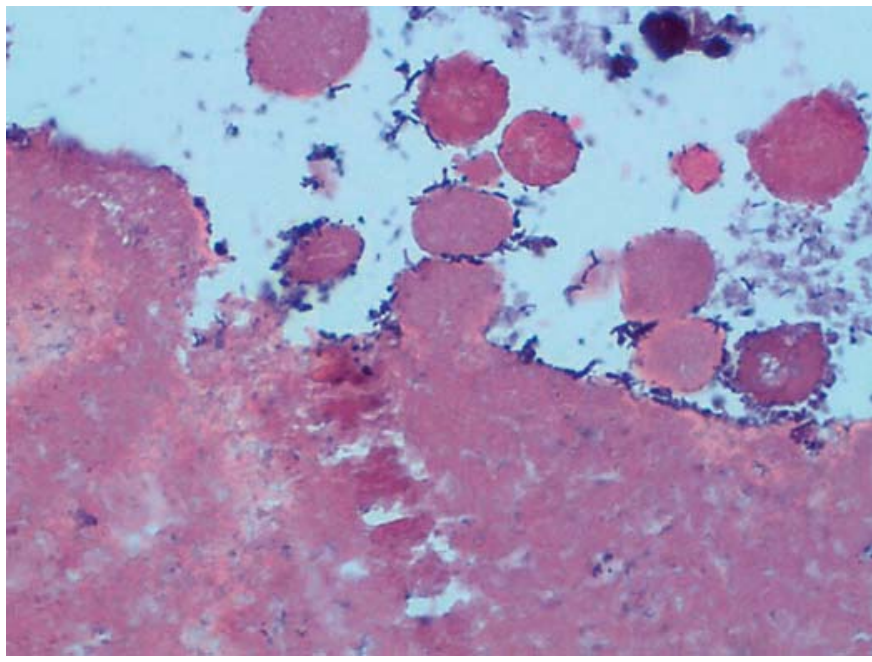

Fig. 12. Round tissue structures at the edge of mummified tissue suggesting a specific process of nervous tissue degradation. HE, $\times 400$.

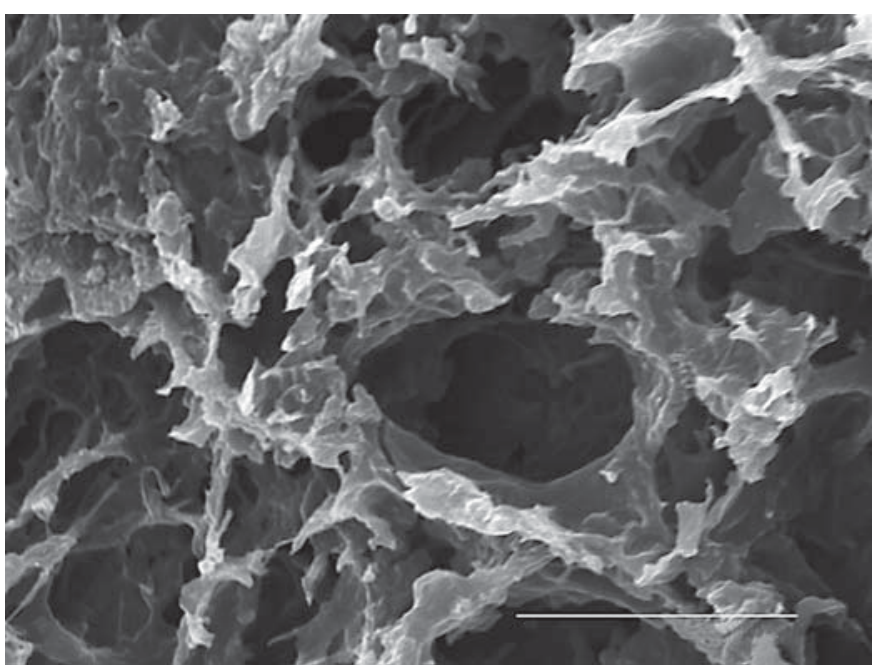

Fig. 14. High-power view of scanning electron microscopy showing $3 \mathrm{D}$ images with a reticular pattern and a central vascular space in one of the mummified intracranial samples. Scale bar: $20 \mu \mathrm{m}$.

nizable myelin sheaths in a 1,500-year-old bog corpse without providing drawings or photographs. More recent reports have provided information on isolated individuals from different locations such as Egypt [9], Denmark [10], France [6], the South African Savannah [11] and Korea [12], but the largest microscopically analyzed series, to our knowledge, corresponds to 15 unrelated cases from 


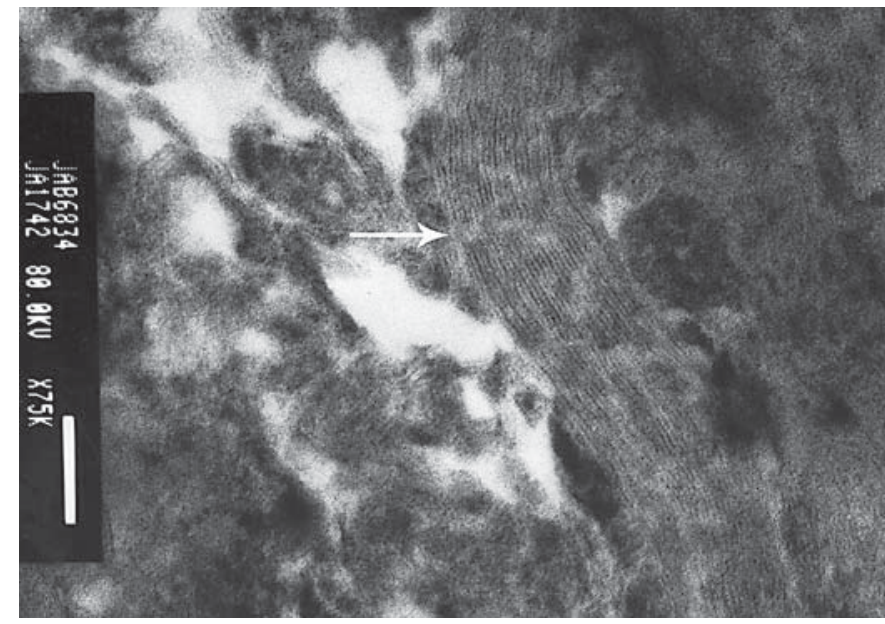

Fig. 15. Transmission electron microscopy of mummified intracranial tissue from individual No. 41 showing periodic laminar structures consistent with myelin sheaths. $\times 75,000$. Scale bar: $100 \mathrm{~nm}$

the desert of Northern Chile from $1000 \mathrm{BC}$ to $1500 \mathrm{AD}$ [5]. Using several histochemical stains, the latter study provided convincing evidence of the relatively good preservation of the brain tissue in the mummies found in addition to proof of intracranial hemorrhagic lesions. Much older, mummified, human, nervous tissue was reported in the Tyrolean Man [13], which very closely resembles ours depicted in figure 10 showing myelin layers, but the Tyrolean Man was a frozen mummy, in which, as mentioned, better preservation can be expected. Finally, the oldest well-documented brain tissue reported in a scientific article is, to our knowledge, that of Pääbo et al. [14], who were able to amplify mitochondrial DNA from 7,000-year-old brain tissue, although no histological evidence of the tissue type was presented at that time, and the classic report by Walter in which two cerebriform fossilized human remains were preserved together with parts of a woolly mammoth at a site near Moscow [15].

Our report is unique in several aspects: first, it describes the simultaneous finding of 4 non-frozen mummified remnants of the human central nervous system in a small burial; second, these subjects belong to a very unique, not well-known and isolated Mediterranean community dating as far back as the Mediterranean Bronze Age, some 3,000 years ago, and, third, it carefully describes and provides evidence of very good spontaneous tissue preservation confirming its nervous tissue origin by the combined use of traditional and high-resolution microscopic techniques. In a very recent report [6], a medieval mummified brain was analyzed by several sophisticated methods, including gas chromatography, mass spectroscopy, CT, MRI and histology, the latter producing very good images of nicely preserved neuronal elements [6]. These authors suggest preservation due to adipocere formation made possible by a humid environment coupled with acidic clay soil.

But, what can possibly explain such unusual preservation of an otherwise fragile matter in the subjects of our report? After several multidisciplinary analyses of the burial, it is now becoming evident that this was a very special site. First of all, the presence of sodium nitrate and gypsum in the cave suggests a relatively dry environment that has enabled the preservation of the organic material and contributed to the natural mummification [16]. Also, decomposition of the human bodies created a special environment that produced, for example, various PCR inhibitors, mainly Maillard and humic substances [17]. Therefore, we hypothesize that a unique combination of the dry climate of the interior of the small island, coupled with the elevated location of the cave, precluding exposure to rain and ground moisture, the known existence of dry air currents inside the cave, an adequate composition of the acid cave soil and walls, rich in sulfates and plaster and, finally, the covering of the bodies with plants, which could have add anti-microbial properties [18, 19], all provided a suitable environment for rapid desiccation and conservation of the bodies, which were able to escape human curiosity for the last three millennia and have now been preserved for science.

\section{Acknowledgments}

This work was supported by grant CGL-2008-00800/BOS. We thank Dr. Teresa Ribalta for helping with the microscopical review of brain tissue, and Cristina Durana, Elena Rull and the Serveis Cientificotècnics de la Universitat de Barcelona for their excellent support in electron-microscopic techniques.

References

Pathobiology 2012;79:239-246 
4 Mekota AM, Vermehren M: Determination of optimal rehydration, fixation and staining methods for histological and immunohistochemical analysis of mummified soft tissues. Biotech Histochem 2005;80:7-13.

5 Gerszten PC, Martinez AJ: The neuropathology of South American mummies. Neurosurgery 1995;36:756-761.

-6 Papageorgopoulou C, Rentsch K, Raghavan M, Hofmann MI, Colacicco G, Gallien V, Bianucci R, Ruhli F: Preservation of cell structures in a medieval infant brain: a paleohistological, paleogenetic, radiological and physico-chemical study. Neuroimage 2010;50:893-901.

7 Elliot-Smith G: On the natural preservation of the brain in the ancient Egyptians. J Anat Physiol 1902;36:375-381.
8 Aichel O: Über Moorleichen, nebst Mitteilung eines neuen Falles (2.5jähriges Mädchen von Röst in Dithmarschen). Anthropol Anz 1927;4(suppl II):57-73.

$\checkmark 9$ Scott JW, Horne PD, Hart GD, Savage H: Autopsy of an Egyptian mummy. 3. Gross anatomic and miscellaneous studies. Can Med Assoc J 1977;117:464-469.

10 Tkocz D, Bytzer P, Bierring F: Preserved brain in medieval skull. Am J Phys Anthropol 1979;51:197-202.

11 Eklektos N, Dayal MR, Manger PR: A forensic case study of a naturally mummified brain from the bushveld of South Africa. J Forensic Sci 2006;51:498-503.

12 Kim MJ, Oh CS, Lee IS, Lee H, Choi JH, Lim DS, Yi YS, Han WJ, Kim YS, Bok GD, Lee SD, Shin DH: Human mummified brain from a medieval tomb with lime-soil mixture barrier of the Joseon Dynasty, Korea. Int J Osteoarchaeol 2008;18:614-623.

-13 Hess MW, Klima G, Pfaller K, Kunzel KH, Gaber O: Histological investigations on the tyrolean ice man. Am J Phys Anthropol 1998; 106:521-532.
14 Pääbo S, Gifford JA, Wilson AC: Mitochondrial DNA sequences from a 7000-year old brain. Nucleic Acids Res 1988;16:9775-9787.

15 Aufderheide AC: The Scientific Study of Mummies, ed 1. Cambridge, Cambridge University Press, 2003.

16 Cabanes D, Albert RM: Microarchaeology of a collective burial: Cova des Pas (Minorca). J Archaeol Sci 2011;38:1119-1126.

17 Simón M, González-Ruiz M, Prats-Muñoz G, Malgosa A: Comparison of two DNA extraction methods in a Spanish Bronze Age burial cave. Archaeol Sci 2011, DOI: 10.1016/j. quaint.2011.04.026.

18 Micozzi M, Sledzik P: Postmortem preservation of human remains: natural and technical processes. Proc 1st World Congr Mummy Study, 1992, vol 2, pp 759-764.

19 Wisseman S: Preserved for the afterlife. Nature 2001;413:783-784. 